\title{
Research of Sorption Characteristics of Tubers Jerusalem Artichoke (Helianthus tuberosus)
}

\author{
Norkulova Karima Tuxtabayevna and Safarov Jasur Esirgapovich*
}

University str.2, Tashkent, 100095, Republic of Uzbekistan

\begin{abstract}
The article discusses the sorption and desorption of water vapor samples of tubers of Jerusalem artichoke. Determined by capillary-porous structure of the samples of Jerusalem artichoke. Shows the effect of drying temperature on the sorption properties of artichoke samples.
\end{abstract}

Keywords: Tubers of Jerusalem artichoke (Helianthus tuberosus); Sorption; Desorption; Structure; Drying; Powder

\section{Introduction}

Jerusalem artichoke - a perennial herb. It produces the drug inulin. Jerusalem artichoke is also a valuable fodder, technical and food culture that are becoming more widely used in various industries $[1,2]$. Obtained from Jerusalem artichoke tubers useful components intended for use as raw materials for foods. Powder artichoke (Jerusalem artichoke flour) contains complex carbohydrate components, represented mainly polysaccharide nature inulin (up to $82 \%$ ), proteins (up to $7 \%$ ), fat (0.3$0.7 \%)$, vitamins (B1, B2, C), pectin (10\%), fiber (7\%), organic acids, macro- and trace elements $[3,4]$.

For long term storage of food products there are various changes (microbiological, enzymatic, biochemical). As a result, products may be damaged. To inhibit microbial growth and enzymatic activity are widely used natural or artificial drying products.

Convective drying is carried out by blowing heated air evenly, thus preserving the taste and avoid "overheating". This means that as Jerusalem artichokes and many other vegetables, fruits, mushrooms, herbs suitable for long-term storage, while they hardly lose they contain vitamins and minerals.

The technological process of IR drying Jerusalem artichoke and vegetable-fruit based on the fact that the infrared radiation of a certain wavelength is actively absorbed by the water contained in the product, but not absorbed by tissue drying product, so moisture removal is possible at low temperature $\left(40-60^{\circ} \mathrm{C}\right)$, which allows almost completely preserve vitamins, bioactive substances, natural color, flavor and aroma are dried product [5].

\section{Objects and Methods}

Jerusalem artichoke tubers sorption properties play an important role in the processed food, for transport and storage. Sorption physico-chemical process in which the absorption and retention of product gases and vapors (volatiles) from the environment.

The process of hydration and moisture return the product takes place before the acquisition of the equilibrium moisture content at which the pressure of water vapor in the air and on the surface of the product are equal. The equilibrium moisture content depends mainly on the chemical composition and the condition of the product and also the relative humidity and temperature. Relative humidity is characterized by the degree of saturation of moisture in the air and is expressed as a percentage [6,7].

The technique of water vapor sorption samples Jerusalem artichoke is to establish the equilibrium concentration of sorbed substance at a given partial vapor pressure.

High vacuum sorption apparatus consists of molybdenum glass vessel Mak Ben, containing the balance quartz spring suspension for the test samples. Measurements were carried out at a residual pressure of $10^{-3}-10^{-4}$ torr and $298 \mathrm{~K}$ using a cathetometer $\mathrm{KM}^{-8}$.

\section{Results and Discussion}

For sorption and desorption tests the ability of artichoke samples accurately weighed samples are hung on Mak Ben and measured using the $\mathrm{KM}^{8}{ }^{88}$, the initial position of which must coincide with the lower end of the spring balance at a given temperature and in this position, the system is evacuated with a vacuum pump for 3-4 h. The test solute (liquid nitrogen cooled) pumped $3 x$ freezing and thawing for 2-3 hours.

To obtain a water vapor sorption isotherm samples needed artichoke 7-8 (points) atdifferent relative humidity.

Sorption and desorption of water vapor at $293 \mathrm{~K}$ on the tubers of Jerusalem artichoke (Helianthus tuberosus). The results are shown in Table 1.

On the basis of the sorption isotherms of water vapor samples of artichoke on the BET equation calculated monolayer capacity, specific surface area, total volume of vapor and the radius of submicroscopic capillaries.

Sorption isotherms are characterized by blurred S-shaped isotherms and have pores of different sizes, which are filled with sorbent transition pairs have large sorption hysteresis (Figure 1).

The data obtained sorption characteristics of samples artichoke sorption and desorption of water vapor are given in the Table 2 .

\section{Conclusion}

Studies conducted sorption and desorption of water vapor samples

*Corresonding author: Safarov Jasur Esirgapovich, Ph.D. in Technics, Head of Department, University str. 2, Tashkent, Republic of Uzbekistan, E-mail: jasursafarov@mail.ru

Received April 01, 2015; Accepted April 21, 2015; Published April 28, 2015

Citation: Norkulova KT, Safarov JE (2015) Research of Sorption Characteristics of Tubers Jerusalem Artichoke (Helianthus tuberosus). J Food Process Technol 6 : 453. doi:10.4172/2157-7110.1000453

Copyright: (c) 2015 Norkulova KT, et al. This is an open-access article distributed under the terms of the Creative Commons Attribution License, which permits unrestricted use, distribution, and reproduction in any medium, provided the original author and source are credited. 
Citation: Norkulova KT, Safarov JE (2015) Research of Sorption Characteristics of Tubers Jerusalem Artichoke (Helianthus tuberosus). J Food Process Technol 6: 453. doi:10.4172/2157-7110.1000453

Page 2 of 2

\begin{tabular}{|c|c|c|c|c|}
\hline \multirow{2}{*}{ Sample } & \multicolumn{4}{|c|}{ Jerusalem artichoke (Helianthus tuberosus) } \\
\cline { 2 - 5 } & $\begin{array}{l}\text { No1 } \\
\text { Vacuum IR drying: } \\
\text {-drying is the temperature - } 65^{\circ} \mathrm{C} \text {; } \\
\text {-vacuum - (-0.8 atm) }\end{array}$ & $\begin{array}{l}\text { No2 } \\
\text { IR drying: } \\
\text { - the drying temperature - 90 } \\
\text { - without }\end{array}$ \\
\hline $\begin{array}{c}\text { Relative } \\
\text { humidity, \% }\end{array}$ & Sorption, \% & Desorption, \% & Sorption, \% & Desorption, \% \\
\hline 10 & 0,20 & 0,50 & 0,45 & 0,60 \\
\hline 30 & 0,50 & 1,40 & 1,40 & 2,10 \\
\hline 50 & 2,40 & 3,40 & 3,60 & 4,70 \\
\hline 65 & 6,20 & 6,90 & 7,50 & 11,20 \\
\hline 80 & 14,70 & 32,50 & 18,20 & 26,50 \\
\hline 90 & 31,50 & 40,20 & 34,20 & 41,50 \\
\hline 100 & 44,00 & 44,00 & 49,00 & 49,00 \\
\hline
\end{tabular}

The value of water vapor sorption samples №1 artichoke tubers at $65 \%$ relative humidity of $6.2 \%$ and samples of tubers of Jerusalem artichoke №2, different drying method, the sorption of water vapor at the same relative humidity is $7.5 \%$.

Table 1: Sorption and desorption of water vapor samples of tubers of Jerusalem artichoke (Helianthus tuberosus).

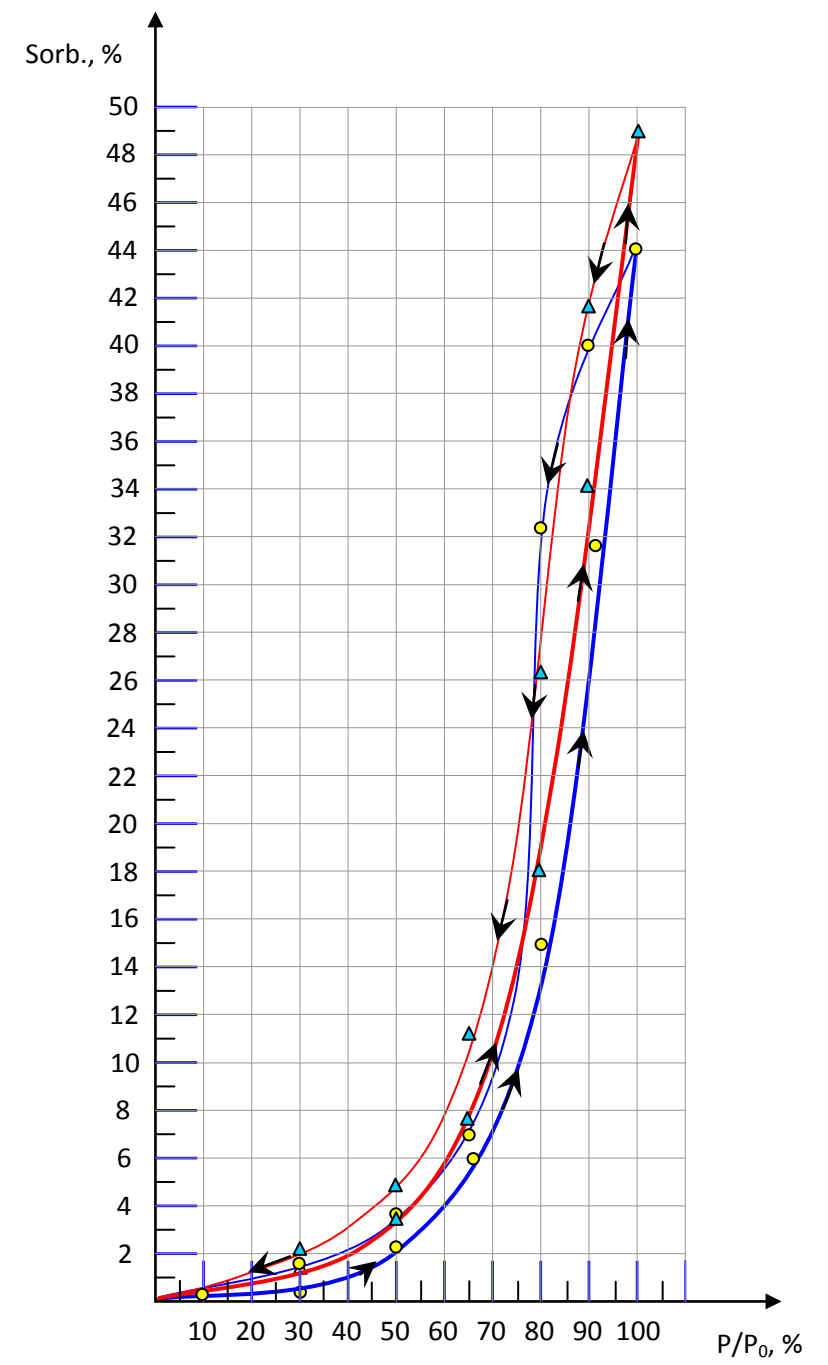

Figure 1: Isotherm curves of water vapor $293 \mathrm{~K}$ tubers of Jerusalem artichoke (Helianthus tuberosus):

№1- • Vakuum-IR drying tubers of Jerusalem artichoke (Helianthus tuberosus);

№2- $\Delta$ IR drying tubers of Jerusalem artichoke (Helianthus tuberosus).

\begin{tabular}{|l|l|l|l|l|}
\hline \multirow{2}{*}{ Sample } & \multicolumn{3}{|c|}{ Jerusalem artichoke } & (Helianthus tuberosus) \\
\cline { 2 - 5 } & \multicolumn{2}{|c|}{ №1 } & \multicolumn{2}{c|}{ №2 } \\
\cline { 2 - 5 } & $\begin{array}{c}\text { Sorption, } \\
\text { \% }\end{array}$ & $\begin{array}{c}\text { Desorption, } \\
\%\end{array}$ & $\begin{array}{c}\text { Sorption, } \\
\%\end{array}$ & $\begin{array}{c}\text { Desorption, } \\
\%\end{array}$ \\
\hline Monolayer capacity, $x_{m^{\prime}} g / g$ & 0,0052 & 0,0166 & 0,0196 & 0,0370 \\
\hline Specific surface, $S_{s p .} m^{2} / g$ & 18,38 & 58,35 & 68,89 & 130,07 \\
\hline Total pore volume, $W_{o^{\prime}}, s m^{3} / g$ & 0,440 & 0,440 & 0,490 & 0,490 \\
\hline radius of the capillary, $r_{k^{\prime}} A$ & 478,78 & 150,81 & 142,25 & 75,34 \\
\hline
\end{tabular}

Table 2: Capillary-porous structure of the samples.

artichoke parameters determined porous structure and revealed that the test samples drying in vacuum at $65^{\circ} \mathrm{C}$ sample No.1 reduces the sorption of water vapor in comparison with the sample No. 2.

\section{References}

1. Ryazanova TV, Dorofeeva LA, Bogdanova AV (1997) Chemical composition of the vegetative part of Jerusalem artichoke and its use. Forest magazine.

2. Pasko NM (1991) Jerusalem artichokes for fodder, technical, food, medical and environmental objectives // III All-Union Scientific-production. Conf. -Odessa.

3. Sidorenko SM, Gorshkov (2003) A method for producing dried tubers of Jerusalem artichoke M.F.

4. Liflyandskiy VG (2006) Vitamins and minerals. From A to Ya. -Sankt Petersburg Publishing House "Neva".

5. Ginzburg AS (1973) Fundamentals of the theory and technology of drying foods M. Food Industry.

6. Kowalska LP (1997) The technology of food production. Ed. LP Kowalska. M: Kolos.

7. Norkulova KT, Safarov JE (2010) Investigation of sorption and desorption of herbs, Chemical technology. Control and management. 